\title{
Translating text into space for mapping the past territory of a city: a study on spatial development of Dhaka during Mughal period
}

\author{
Mashrur Rahman ${ }^{*}$ (D, Kawser Bin Zaman and Roxana Hafiz
}

\begin{abstract}
Background: There is no established methodology for mapping the past territory of cities from text based historic information. As a result, the past territories of cities often remain obscure due to lack of spatial representation.

Methods: This article proposes a GIS based methodology to study the spatial development of cities in early times. It focuses on 'historical geography' which has been evolved as an interdisciplinary field bridging the divide between history and geography. Analyzing different 'named places' mentioned in the historical sources it first tries to develop a clear understanding about the physical development of Dhaka during Mughal period, which was then the capital of Bengal. Later it georeferenced those named places and applied GIS based techniques to map the past urban territory.

Results: The result shows the spatial development of Dhaka in Mughal period and how it undergone changes in pre and post Mughal era. The area of Dhaka in Mughal period was quantified $12.93 \mathrm{~km}^{2}$ which was comparable with any other top cities of the world in the 17th century. Application of GIS also extends the scope of the study to explain spatial pattern of the localities and the geological aspects of early urban development of Dhaka.

Conclusions: Analyzing different historic sources of information (both texts and maps), it has tried to define the past extent of Mughal Dhaka which has been missing till now. The methodological prospects of this study and its application will not only be limited in context of Dhaka, but for other cities as well.
\end{abstract}

Keywords: Historical geography, Spatial development, GIS, Georeferencing, Cartographic generalization

\section{Background}

The recorded history of Dhaka spans a timeframe of over 400 years. It has grown from an obscure and tiny settlement to a burgeoning metropolis-rising to prominence during the Mughal era. It was established as the capital of Bengal by the Mughals in 1610 (Karim 1964; Dani 1962; Ahmed 1986). Very few cities in the world have such a long time of uninterrupted and organized existence like Dhaka as a historic city. However, there is not any clear consensus about the spatial extent of the city during the early pre-Mughal and Mughal period (Rahman et al. 2014). Some researches tried to explain the morphological evolution of Dhaka during Mughal times (Mowla

*Correspondence: mashrurmishu@yahoo.com Department of Urban and Regional Planning, Bangladesh University of Engineering and Technology, Dhaka, Bangladesh
1997; Nilufar 1997, 2004; Ferdous 2012) while others mostly focused on administrative and socio-cultural perspective with a gross generalization of its spatial pattern (Islam 1996; Rabbani 1997; Kabir and Parolin 2012). Again, some studies analyzing the spatial development and growth of Dhaka were limited to recent time frame. Although some maps are used in different studies to represent Mughal Dhaka, these maps are used only for mere illustration prepared without a clear-cut methodology. The urban extent of Dhaka defined by those maps differs significantly from the description of historians (Rahman et al. 2014). As a result, the sequential urban expansions of Dhaka in different time periods since the Mughal era are misleading.

Historical sources provide important information about the past landscape of cities. But historic researches in most cases try to explain the evolution of the city only 
from administrative, political or socio-economic perspectives with little emphasis on space (Knowels 2008). The past territories of cities are often obscure due to lack of spatial representation. Firstly, it is a challenging task to accumulate the required information from the text based resources as these are fragmented and incoherent sources of information. Secondly, there has been no established methodology to correctly map spatial information extracted from history. As a result, it gives rise a major interdisciplinary challenge to create a spatial representation of past territory of cities from text based historical resources (Piatti and Hurni 2007; Knowels 2008). However, since 1990s, researchers have sought to explore the way to integrate space into historical analysis. Scholars from many branches of historical study are trying to apply geospatial techniques to explore spatial relationships and thereby reconstructing past places and landscapes (Alexander 2015; Philo 2000). As a part of this process, historical geography has evolved as an important interdisciplinary field to reconstruct past urban territory of cities.

Historical geography aims to explore and analyze the spatial information available in historical resources. Organizing the spatial information and making spatial representation of them using maps can give a more meaningful result (Baker 2003; Piatti et al. 2009). The emergence of digital technology especially potential of GIS as an analytic tool in historical research is widely recognized for spatial representation of the text based qualitative data (Ayers 2010; Cooper and Gregory 2011). It has greatly reduced the complexity of spatial information and thereby increased the scope to represent the map according to the desired purpose. Hence given the unavailability of appropriate maps, historical geography and application of GIS in this field can play a vital role for mapping the past urban territory of a city. This study will firstly try to develop a clear understanding about the spatial territory of Dhaka in Mughal period based on different historical studies. Later based on the findings, it will try to prepare a GIS based map of Dhaka and analyze the shape of the 17th century Mughal city and how it had undergone major changes in pre and post Mughal periods. Also, it will try to connect the geological aspect of Dhaka's spatial development in early times.

\section{Historical geography}

Geography focuses on place while history on time. In both of their confluence, historical geography deals with places of past period as a common discourse between history and geography (Mitchell 1954). Earlier, the scope of historical geography was only limited to the study of geography of the past periods. From the eighteenth to early twentieth century the core concern of historical geography was centered on the geography of holy lands, change of political frontiers and different geographical discoveries and explorations (Smith 1894; Smith and Bartholomew 1915; Jones 1932; Holdich 1916; Butlin 1993; Baker 2003). A significant definition of the discipline was provided by Darby (1962). He emphasized mapping historical sources in order to demonstrate regional differences and changing landscapes during past periods. It put much importance on the cross sectional study of the places at some critical times to discern the pattern of past changes. Hence, according to Darby's view, a new dimension concerned with 'changing landscape' was added to the traditional thoughts of 'geography of the past'.

Darby's thoughts on historical geography undoubtedly have been very pioneering and influential. Much of the works done until now involves reconstructing the past territories and visualizing the change throughout the times (Knowles 2008). However, some think that in this attempt to establish historical geography as a separate discipline Darby marginalized its scope (Baker 2003). According to Darby, for historical geography the source may be historical but the methodology should be essentially geographical. But, historical geography can share both historical and geographical methodology because there is a definite method of enquiry for historical sources to be analyzed as well. That is why a more logical approach should be to broaden its scope instead of classification or marginalization to capture more of its diversity. Journal of Historical geography publishing scholarly articles since 1975 widens its scope through the following definition: "the writings of scholars of any disciplinary provenance who have something to say about matters of geographical interest relating to past time" (Jalali and Keivani 2013).

The main source of spatial information for historical geography studies are historic maps and texts extracted from books, archival documents, records, travelers' description etc. However, to give spatial representation of text based documents is really a challenging task due to the spatial uncertainty of location and imprecision of historical data (Knowles 2008). The study of geography by extracting the places from text based documents, records or any other historical resources is not a new phenomenon but has been continued for a long time (Sharp 1904; Woolf 1977). But this topic gained a momentum in 1990s when the idea of the spatial paradigm or 'spatial turn' propagated among several human sciences including history (Soja 1989). This spatial paradigm witnessed many researchers engaged closely with history and literature and thereby to make spatial representation of qualitative data. Since then a number of researches have been carried out searching for the interactive methods and of mapping the past. With the advancement of technology, especially 
application of GIS is increasingly acknowledged as an important advancement in the historical geography.

GIS has some important advantages for creating new insight into the spatial development of the past. It can include the location explicitly where they were placed. Secondly, it allows integrating data from different sources. Finally, it enables different types of spatial analysis and visualizes the data and its changing pattern. In fact, the main essence of GIS in historical geography is that it can incorporate qualitative data (like historical text) for spatial analysis. Ray's (2002) study of the Salem Witchcraft Trials can be a good example of it where he used text based information like court documents and transcription of trials along with maps to understand the spatial aspect of the trial. Cooper and Gregory (2011) mapped the 'English Lake District' based on literary description. The research focused on the ways in which GIS can be used to explore the spatial relationships between two textual accounts of tours of the English Lake District: The first one is by poet Thomas Gray, in 1769; and the later one is Samuel Taylor Coleridge in 1802.

Lots of works in historical geography have been carried out analyzing the change of past landscape within predetermined administrative boundaries (Gregory et al. 2002; Skinner et al. 2000; Gregory and Healey 2007). However, in most cases the past territory and boundaries were unknown and could not be defined explicitly. In such circumstance, text based information like named places and localities help to define the boundary. Here, territory of a city can be described in terms of the localities encompassing the concentration of human activities as a cohesive unit of settlement (Soja 1989). However, not much works have been done to reconstruct the past territory of an area or cities except some few studies. Berman (2005) tried to define the territory of Chinese administrative units in past times analyzing the historic text using GIS. More recently, Alves and Queiroz (2013) developed a digital methodology that studies literary places in the context of the contemporary urban history of Lisbon. Name of localities, neighborhoods, important landmarks mentioned in the texts were identified and recorded in a GIS database. Lisbon's municipal place- name database, street guides from the second half of the eighteenth century and the first half of the nineteenth century were used to identify locations. Finally based on the names of the locations, the maps were generated illustrating the evolution and growth of city in different time periods.

Although historic geography is a diversified field, tracing the past geography and understanding its changes remained the core concern of this discipline. Among several broad issues, defining past boundaries and change of political frontiers gained much importance in the early studies of historical geography. But there are some challenges which need to be addressed in this concern. The present jurisdiction of an area may not represent its historic territory in the past time period. Again, lack of maps and other relevant sources make it difficult to reconstruct the past boundary of an area. Very few researches have been carried out negotiating this challenge for explicitly mapping the territory of past areas or cities. The named places like the landmarks, localities can be a valuable source of information to reconstruct the past territories and to understand the changes in different times. This can be a very fertile ground for the historical geography researches. Incorporating text based information in GIS along with maps and other sources can open up a new dimension to the historic geography developing a close insight about the past.

\section{Literature review}

Different archival sources, historic books and studies provided vital sources of information for the past history of Dhaka. One of the most unique and extensively documented sources was the Baharistan-i-Ghaibi. It is a 17thcentury chronicle and was written by Mirza Nathan, a Mughal army officer, (later translated by Assam Government in 1936) on the history of Bengal, Cooch Behar, Assam and Bihar under the reign of Mughal emperor Jahangir (1605-1627). The only other source of the time Tuzk-e-Jahangiri, the official memoirs of the emperor only briefly mention a few events in Bengal. Mirza Nathan's account follows the campaign of Islam Khan and the establishment of Dhaka as the Mughal capital. The book describes the initial expansion of the city under the Mughals and early establishments.

The earliest study about Dhaka was carried out by Taylor (1840) in his book A Sketch of topography and statistics in Dacca. The book gives a general history and mainly focuses on the topographical description of Dhaka. Although written in British Period, the book provides some important information about earlier Mughal period especially about the area and population.

The first modern research on Dhaka appeared in 1956 by Syed Muhammed Taifoor. The name of the book is $A$ Glimpse of Old Dhaka, a seminal treatise on the historical evolution of the city. Later in 1962 Ahmad Hasan Dani, the Pakistani historian made another significant contribution through his book Dacca: record of its changing fortune. The book takes a look on Dhaka from Pre-Mughal to early Pakistan period. The book tries to explore the origin and evolution of the city. The sequential growth of Dhaka has been briefly described along with the socioeconomic and political factors those influenced the historic development of Dhaka.

Perhaps the most important book on the history of Dhaka was written by Professor Abdul Karim in 1964. In 
the book Dacca: the Mughal capital, a detailed description on origin and development Dhaka was given during Mughal period. Through an extensive analysis of the localities the writer tried to define the boundary of Dhaka during Mughal regime. Due to unavailability of appropriate maps, his description about the early neighborhoods provides an authentic source of information about the spatial extent of Mughal Dhaka. Moreover, important hydrographical and geological aspects like rivers, water channels and connection of Dhaka with the regional water network have been described in his book which helped to recreate the past landscape of Dhaka.

Later, contemporary historians like Sharifuddin Ahmed and Muntasir Mamoon contributed further on the historic evolution of the city. The book Dacca: a study of urban history and development by Sharifuddin Ahmed provides some important information especially about the physical and population growth of Dhaka during British period. Muntasir Mamoon in his book Dhaka: Smriti Bisritir Nogori described how and when different neighborhoods of Dhaka evolved. Also, a vivid description of historical background was provided for most of the localities. This helped to get idea about the chronological development of different $\mathrm{c}$ and neighborhoods.

\section{A brief description of Dhaka}

Today's Dhaka stands on a long history dated back to 7th century A.D. Before the Mughal period, Dhaka was successively ruled by Sena, Turkish, and Afghans (Dani 1962). Professor Abdul Karim, based on the inscriptions suggested that Dhaka gained some importance during the Sultanate period in 16th century (Karim 1964). During the reign of Emperor Akbar, it was a thana or Mughal outpost (Dani 1962) which led to the growth of brisk of urban activities especially the rise of local manufacturers and traders. The status as a thana set the initial stage of growth of the city. Within a very short period of time, with the advent of Mughals, Dhaka rose from a humble position of Mughal military outpost to a burgeoning metropolis. From a small town of few thousands of population, the city has now become one of the largest megacities of the world. It is the main focus of administrative, commercial, social and educational activities of Bangladesh. Presently, the influence of the city goes beyond the administrative boundary and takes the shape of a mega urban region. The size of Dhaka megacity is $1528 \mathrm{~km}^{2}$ with a population of 14.5 million (Dewan and Corner 2013).

The city is located in one of the largest delta system of the world formed by the Ganges, Brahmaputra, and Meghna basin. Situated in the center of the delta, Dhaka had a well command all over the water routes in early times. The geographical location of Dhaka with its network of inland waterways made it an important location both strategically and commercially. The present Dhaka is surrounded by rivers in all sides. However, the old part of the city lies on the bank of Buriganga River and early urbanization of Dhaka took place in the confluence of Buriganga River and Dhulai Canal (Fig. 1). The city is surrounded by floodplains in the periphery with a higher ground in the central part. Geomorphic classification reveals that low lying floodplain constitutes the largest area, followed by the higher terraces (Kamal and Midorikawa 2004). Under the pressure of ever increasing population, urban expansion has encroached on marshy wetlands in the periurban areas.

\section{Methods}

The most vital part of the study was reviewing various archival documents, chronicles, historic books, administrative reports about the past history of Dhaka. Two historical maps of ancient Dhaka were incorporated in this study. One is the Rennell's Map of 1778 (Fig. 2) and the other is the Surveyor General's Map in 1859 (Fig. 3). The earliest map available for Dhaka was prepared by James Rennell in 1778, nearly after the end of Mughal reign. Only Rennell's map can depict the early course of the River Buriganga as presently, the river has been shifted away (Fig. 1). So, this map was used as the base map in this study representing the Mughal Dhaka. The second map used in this study was prepared during the colonial period. It was of a larger scale and more detailed. The city territory of Dhaka can easily be delineated from this map. This allowed comparing the spatial development of Dhaka during Mughal and post Mughal period. Both of these two maps were superimposed on the present map of Dhaka and were georeferenced based on the selected GCPs (Ground control points). GCPs were assigned to characteristic objects (road intersection, peaks and course of canals or water streams, fort, bridge etc.) common in both the existing and the historical maps.

Defining the urban territory in GIS from text based historical sources requires two steps:

1 Georeferencing the text based information.

2 Defining the boundary from the georeferenced data.

\section{Georeferencing the text based information}

Historical sources may provide information regarding the spatial development of a city. However, in most cases, historical sources lack spatially explicit information in text (Doherty et al. 2011). So it is a major challenge to georeference those information in GIS due to spatial uncertainty of locations. To come over this uncertainty, different methods have been evolved. Wieczorek et al. (2004) have proposed four such methods of geo-referencing textual 


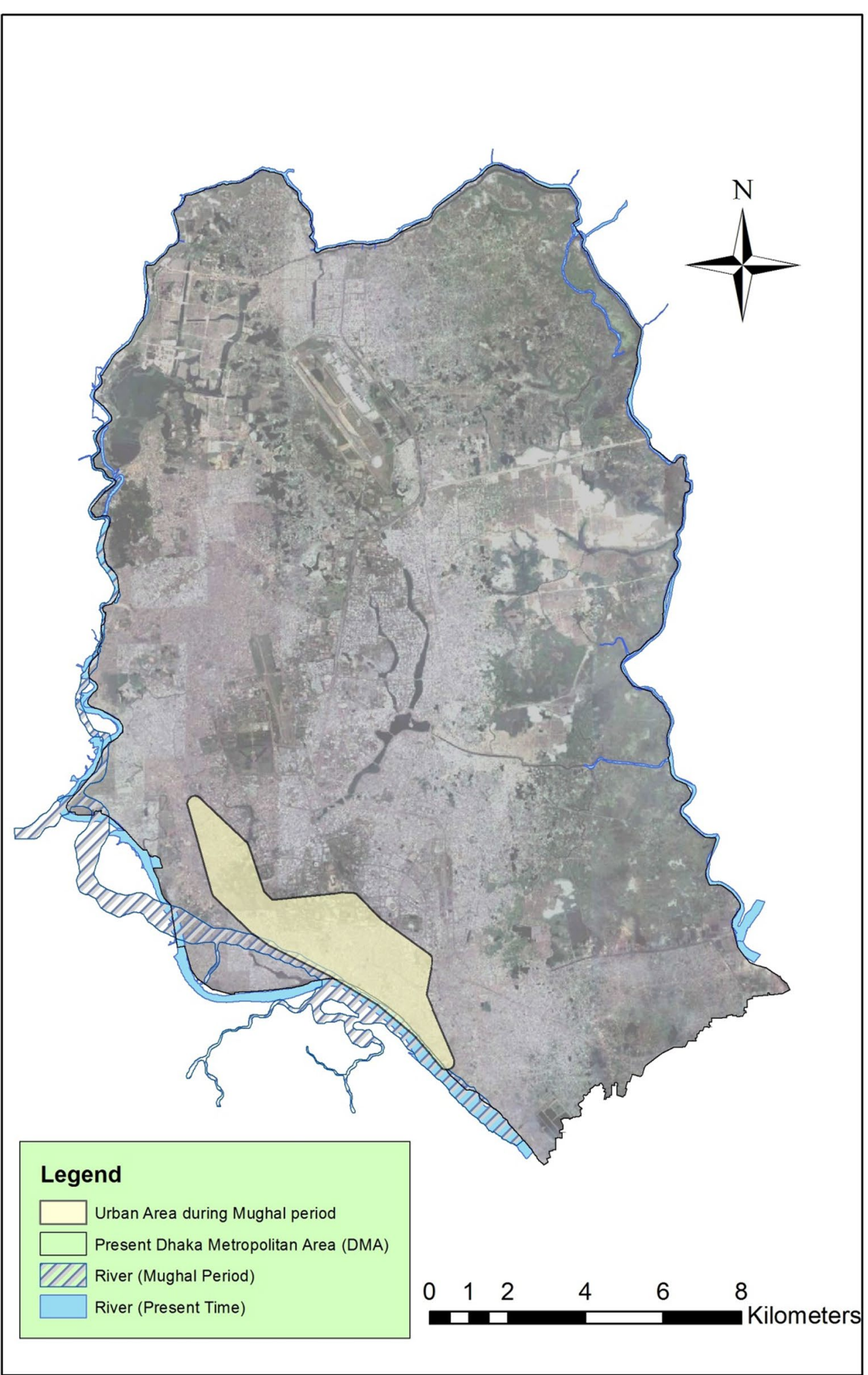

Fig. 1 Urban territory of Dhaka during Mughal period in comparison with present times 


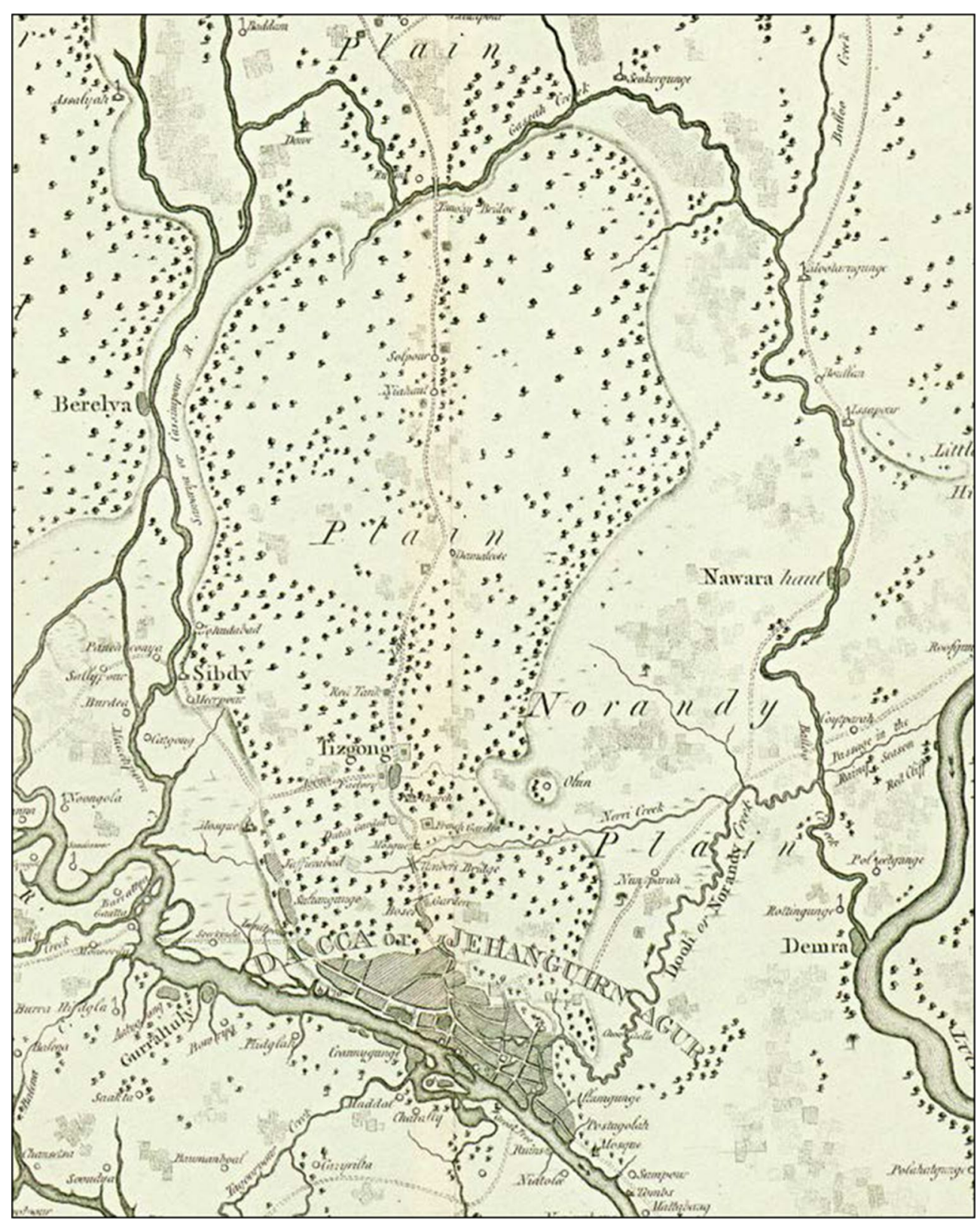

Fig. 2 Map of Dhaka in 1778 prepared by James Rennell

data such as point method, shape method, bounding box method and point-radius method. In the first method, a single coordinate pair is assigned for each place while the other three methods require the known extent of a locality along with the location. But in context of this study, more detailed requirements for other methods like point radius and shape methods are missing in historical sources. Therefore, Point method was preferred over the other methods for georeferencing the named places. Firstly, the spatial information like the named places (localities), offsets (may be along a route or in orthogonal direction) and special landmarks (like location of bridge, sculpture, tree etc.) which can be geo-referenced were gathered from the historical sources. Secondly, for each of these places a single point was assigned. Later these points were geolocated on the base map using ArcGIS 10. The geographic centre of the named place is recommended as the location because it describes a point where the uncertainty due to the extent of the named place is minimized. But if no such center is found, then any point that fall within the boundary of the place can be used for georeferencing (Wieczorek et al. 2012). 


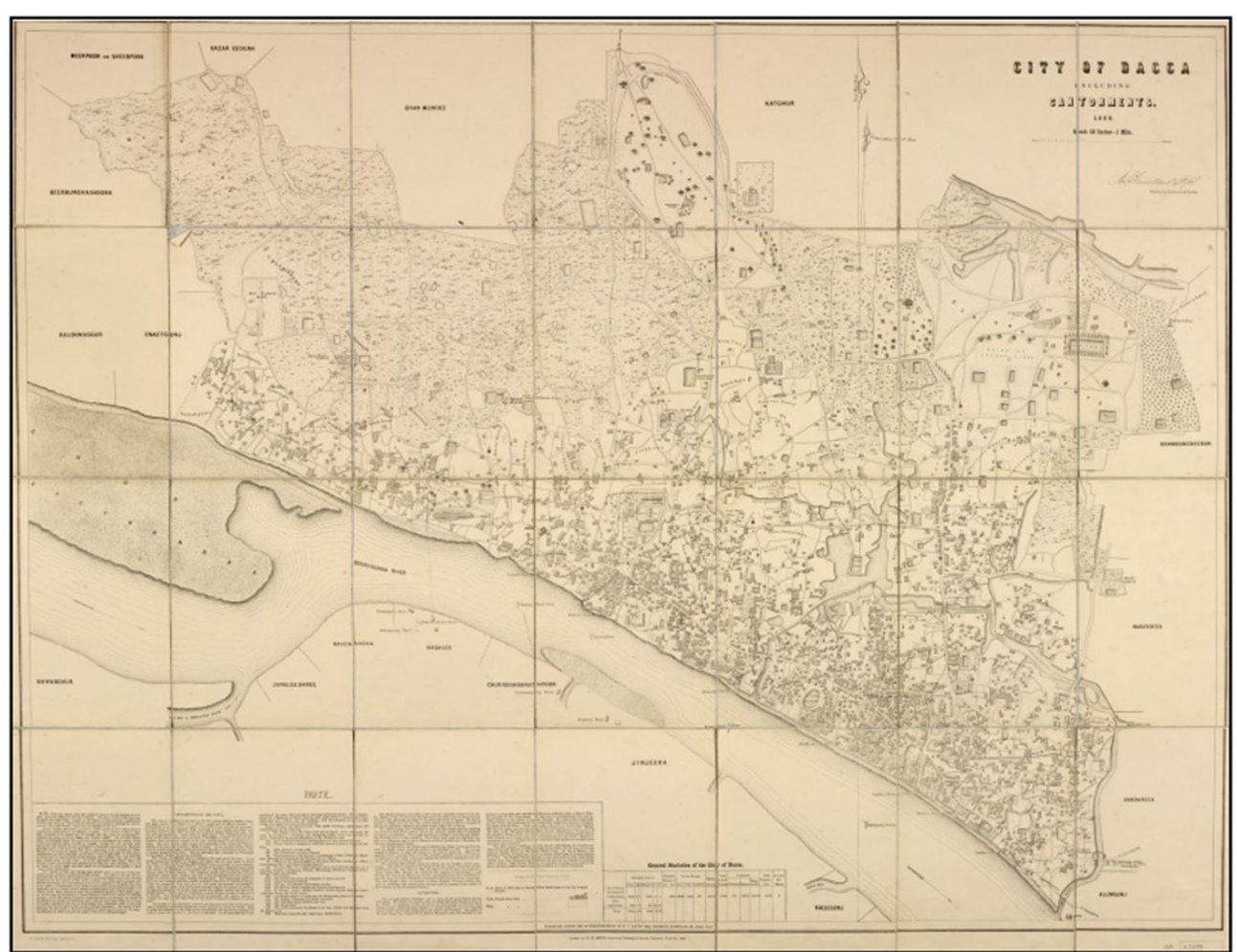

Fig. 3 Map of Dhaka in post-Mughal period (Surveyor General's Map 1859)

\section{Defining the boundary from the georeferenced data}

The Once the localities have been located on the map, it is to delineate the boundary of the city (a polygon feature) based on the 'point' based locations. Narrated spaces don't have definite borders (Piatti et al. 2009) but it has to be created based on the locations extracted from narrated texts. It requires advanced spatial analysis and cartographic techniques to define the spatial territory from place based locations. There are different cartographic generalization techniques available for this task. Aggregation is the most common generalization technique which can be defined as creating a single map object (a polygon representing an area) by grouping multiple map objects (may be point, line or polygon features) (Auer 2009). Hence, aggregation method simplifies complex map objects for spatial representation. In the literature of GIS, various methods of aggregation have been studied till to date. A common method applied is density estimation where boundary is defined based on the density and proximity of the location (Alves and Queiroz 2013; Cooper and Gregory 2011). Hu et al. (2004) presented a short exploration of the topic and identified 'Convex Hull', as the best technique for aggregation. Convex Hull is a geometric algorithm that involves representing a range or extent by drawing an envelope (a polygon feature) around the outer boundary of a group of points.
An advancement of Convex Hull, is the ShrinkWrap Hull method (Revell 2004). This technique is proved giving a more accurate result while creating a boundary by aggregating point based locations (Auer 2009; Rainsford and Mackaness 2002; Revell 2004). In this study ShrinkWrap Hull technique has been used for aggregating the points indicating early localities and to create a boundary which is a polygon feature (ArcGIS 10 allows SrinkWrap Hull method for aggregating the points into polygon). It creates an envelope of the perimeter around the points. Overlay of maps in GIS makes it possible to create multirepresentation framework. Thus changes of urban territory can be compared and visualized in different time periods. It allows better interpretation of maps in comparison with other important features like geological setting of the city.

\section{Urban territory of Dhaka in the past}

\section{Pre- Mughal period}

There is no specific document from which the locality names of pre-Mughal period can be extracted. However, the extent of the city can be drawn from Baharistan$i$-Ghaibi, a 17th-century chronicle written by Mirza Nathan. Mirza Nathan identified a Pakur tree (located in 'Pakurtuli' area) which he described as the boundary between old Dhaka (Pre-mughal area) and new Dhaka 
(Nathan 1936). Near Pakurtuli, Islam Khan dug an artificial canal named Babubazar canal from the branch of Dhulai Canal (Dhulai River in that time ${ }^{1}$ ) connecting to Buriganga river. Thus it is clear that, the canal was dug to separate the newly developing city from the old one. Mirza Nathan in his book Baharistan-i-Ghaibi also stated about the existence of a fort named Beg Murad's fort (located at present Mill barrack area in Alamganj) in the east of city at the mouth of Dhulai Canal. It was built in pre-Mughal period which bore the testimony of Pathan establishment (Haider 1967). So, it can be assumed that, the fort and the Pakur tree was the east and west limit of the city and its extent was confined within the circuit of the old Dhulai Canal in pre-Mughal time. Historian Dani (1962) also asserted that the localities enclosed by the canal prove their origin in pre-Mughal period for their connection with non-Muslim communities. These are the localities inhabited by artisan classes; for examples Shakharibazar (shell cutters), Tantibazar (weaver), Patuatoli (painters), Jaluanagar (fisherman), Kamarnagar (blacksmiths) etc.

\section{Mughal period}

Taylor (1840), the commercial resident of Dhaka considered the boundary of Mughal Dhaka Buriganga in the south, Tongi in the north, Mirpur-Jafrabad in the west and Postgola in the east which is almost the present city limit of Dhaka. But all the important Mughal establishments were concentrated in the southern part of the city. Also from the Rennell's Map it is clear that these areas are full of trees and gardens. So, to get an idea of the true extent of the city one has to consider the names of the localities from historical sources.

Karim (1964) gave a comprehensive picture about the localities developed during the Mughal period. The main source of the names of the localities was the letter from the Collector of Dacca to Calcutta Board of Revenue in 1790. Moreover, he also considered the name of origin of the localities. The localities having suffices like bagh, tuli, tola, bagicha, pur, bazaar, ganj, khana indicates their Mughal origin and most likely to develop in that time. The locality names also suggest the professional or artisans who inhibit the area. The pre-Mughal area was inhabited by business and artisan classes. However, Mughal area was mostly the place of administrative and military officials. From the collector's letter and analyzing the name of the localities, Karim (1964) finally listed the

\footnotetext{
${ }^{1}$ Earlier, Dhulai River was a branch of Buriganga River. However, the river became an abandoned channel in course of time and was converted into a narrow canal. Later, the entire canal was turned into a box culvert. But, the mouth of the canal can be traced even at present time near Mill barrack area.
}

names of the localities those developed during Mughal period.

However, there were other localities in north and north-eastern part which Karim (1964) did not list but other historians mentioned in different studies. During Mughal period, the city extended to the north crossing the old limit of Dhulai Canal. Nazirabazar (Mamoon 1993), Alubazar (Haider 1967), Malitola (Taifoor 1956), Uttar Moishundee, Dakhshin Moishundee (Mamoon 1993; Haider 1967) were the localities those came under settlement in Mughal period. Further towards the north, two localities named Mahalla Chishtia and Mahalla Shujatpur emerged near Ramna as residential areas of high class Mughals (Taifoor 1956). Near the Old High Court building there was an entrance of Mughal garden which existed until 1904 (Dani 1962). Two mosques named Shahbaz Khan Mosque (Mamoon 1993) and Musa Khan Mosque (Rahman 1991) were built in that time by the Mughals. All these landmarks defined the limit of the past Ramna area (Mamoon 1993). Considering all these historical sources, the localities those existed in Mughal period has been listed below as shown in Table 1 .

\section{Geo-referencing}

The locality names identified in the previous section were geo-referenced. Among different methods point method was used in this study. Among the named places, some localities (Postgola, Alamganj, Jafrabad and Dewanbazar) can be identified from Rennell's map and thereby can be easily georeferenced. For other named places, georeferencing method follows three approaches. Firstly, to represent the named places as single point features, the geographic centers of the localities (for example central market place) were identified to minimize the uncertainty. Secondly, if the existence of such central place is not found, then any place(s) within the locality or defining the boundary of that locality (may be a mosque, monument, fort, bridge) were identified which bear the testimony of Mughal settlement. Thirdly, any offset of certain distance described by famous travelers or historians representing the extent of the city in a particular direction was considered and georeferenced on the map (Table 2).

\section{Locality names}

In fact, in Mughal times, the native city was characterized in terms of Mahalla (localitiy) and the bazaars (marketplaces). The morphological characteristic of the city was such that each locality developed around the market places which still exist today (Mowla 1997; Nilufer 2004; Ferdous 2012; Mishu et al. 2014). The markets were local nodes, used as chawks or square around the road intersections. These bazaars or market places 


\section{Table 1 Localities of Dhaka during Mughal Period}

\begin{tabular}{|c|c|c|}
\hline Growth direction & Name of Localities & Source \\
\hline $\begin{array}{l}\text { Old Dhaka of Pre-Mughal time and subsequent } \\
\text { expansion to the east }\end{array}$ & $\begin{array}{l}\text { Banglabazar, Kaltabazar, Patuatuli, Sutrapur, Rokonpur, Tantibazar, } \\
\text { Jaluanagar, Banianagar, Goalnagar, Shankharibazar, Kamarnagar, } \\
\text { Kumartuli, Ray Shahebbazar, Lakhsmibazar, Farashganj, Alamganj, } \\
\text { Narindya, Postogola }\end{array}$ & Karim (1964) \\
\hline Expansion towards the west & $\begin{array}{l}\text { Chawkbazar, Lalbagh, Bakshibazar, Begumbazar, Enayetganj, Sul- } \\
\text { tanganj, Rahmatganj, Sawarighat, Islampur, Nawabpur, Nimtali, } \\
\text { Dhakeswari, Azimpur, Phulbaria, Pakurtali, Amligola, Hazaribagh, } \\
\text { Maneshwar, Jafarabad, Atishkhana, Mughaltuli, Imamganj, Mahut- } \\
\text { toli, Peelkhana. }\end{array}$ & Karim (1964) \\
\hline \multirow[t]{7}{*}{ Expansion towards the North } & Dewanbazar, Phulbaria, Kayettuli, & Karim (1964) \\
\hline & Nazirabazar & Mamoon (1993) \\
\hline & Alubazar & Haider (1967) \\
\hline & Malitola & Taifoor (1956) \\
\hline & Uttar Moishundee & Mamoon (1993), Haider (1967) \\
\hline & Dakhshin Moishundee & Mamoon (1993), Haider (1967) \\
\hline & Ramna (Mahalla Chishtia, Mahalla Shujatpur) & Taifoor (1956), Dani (1962) \\
\hline
\end{tabular}

\section{Table 2 Geo-referencing of localities}

\begin{tabular}{|c|c|}
\hline Name of localities & Geo-referencing points \\
\hline $\begin{array}{l}\text { Banglabazar, Kaltabazar, Patuatuli, Sutrapur, Rokonpur, Tantibazar, Jaluanagar, } \\
\text { Banianagar, Goalnagar, Shankharibazar, Kamarnagar, Kumartuli, Ray shaheb- } \\
\text { bazar, Lakhsmibazar, Farashganj, Bakshibazar, Enayetganj, Rahmatganj, } \\
\text { Nawabpur, Phulbaria, Pakurtali, Amligola, Hazaribagh, Maneshwar, Mug- } \\
\text { haltuli, Imamganj, Mahuttoli, Malitola, Alubazar, Nazirabazar, Dewanbazar }\end{array}$ & Bazar or market place \\
\hline Islampur & Islam Khan Mosque (1610). (Taifoor 1956) \\
\hline Azimpur & Purana Paltan Lane Mosque (1708) (Shamsuzzoha and Islam 2011) \\
\hline Lalbagh & Lalbagh fort (1678) (Dani 1962) \\
\hline Alamganj & Beg Murad Fort (Pre-Mughal) (Rahman 1991) \\
\hline Dhakeswari & Dhakeswari temple (Pre-Mughal) (Mamoon 1993) \\
\hline Ramna & $\begin{array}{l}\text { Old High court building (Dani 1962) } \\
\text { Hazi Shahbaz Khan Mosque (1679) (Taifoor 1956) } \\
\text { Mir Jumla Gate (1660) (Dani 1962) } \\
\text { Musa Khan's Mosque (18th century) (Rahman 1991) }\end{array}$ \\
\hline Nimtoly & Nimtoly Dewry (18th century) (Mamoon 1993) \\
\hline Peelkhana & $\begin{array}{l}\text { Elephant depot (Map of 1859) } \\
\text { (Haider 1967) }\end{array}$ \\
\hline Begambazar & $\begin{array}{l}\text { Kartalab Khan Mosque (1700) } \\
\text { (Hossain 2013) }\end{array}$ \\
\hline Kayettuli & $\begin{array}{l}\text { Srichack bridge (17th century) } \\
\text { (Hossain 2013) }\end{array}$ \\
\hline Atishkhana & Khan Muhammad Mridha Mosque (1706) (Shamsuzzoha and Islam 2011) \\
\hline Narinda & $\begin{array}{l}\text { Binat Bibi Mosque (1457) (Dani 1962) } \\
\text { Christian cemetery (17th century) (Mamoon 1993) }\end{array}$ \\
\hline Sawarighat & $\begin{array}{l}\text { Choto Katra (1663) (Dani 1962) } \\
\text { Boro Katra (1644) (Mamoon 1993) }\end{array}$ \\
\hline Sultanganj & $\begin{array}{l}\text { Dhanmondi Eidgah (1640) } \\
\text { (Dani 1962) }\end{array}$ \\
\hline Chawkbazar & Chawkbazar Shahi Mosque (1676) (Mamoon 1993) \\
\hline
\end{tabular}


were identified on the maps and were georeferenced as a single point feature representing as a central knot of the localities.

\section{Landmarks}

However, not for all the Mughal localities such market place can be identified. In such cases, old landmarks of Mughal settlements are the key source of information for georeferencing. For example, Ramna was an area resided by high class people in Mughal period. The landmark defining the northern limit was Ramna Gate built by Mir Jumla to remark the entrance of the city (Dani 1962; Karim 1964). Historians agree that Dhaka did not grow beyond this limit in Mughal period. Moreover, the old High Court building, the Shahbaz Khan mosque and the Musa Khan mosque are the selected landmarks defining the limit of Ramna as mentioned earlier. The gate and the mosques still exists today and their location were georeferenced on the map.

\section{Offset}

Apart from named localities, offsets, distance, length, direction mentioned in historical description and texts help to understand the extent of the city in the past. Tavernier's description is an important source of information for the Western limit of the city. Tavernier in 1666 in his travel diary wrote, "Dacca is a great town, but only extended in length because everyone desired to have a house near the side of river. The length of the town is two legues $(9.6 \mathrm{~km})$ " (Tavernier 1889). An offset of $9.6 \mathrm{~km}$ from Postgola, the east limit of the city was considered in Hazaribagh, Jafrabad direction along the riverside.

The Mughal period was the golden era for Dhaka, during which the city expanded dramatically both in area and population. The map prepared based on the georeferenced data shows that Dhaka expanded in all direction during that time (Fig. 4). However, the expansion to the west was the most phenomenal along the course of the river. The length of the city as Tavernier described was

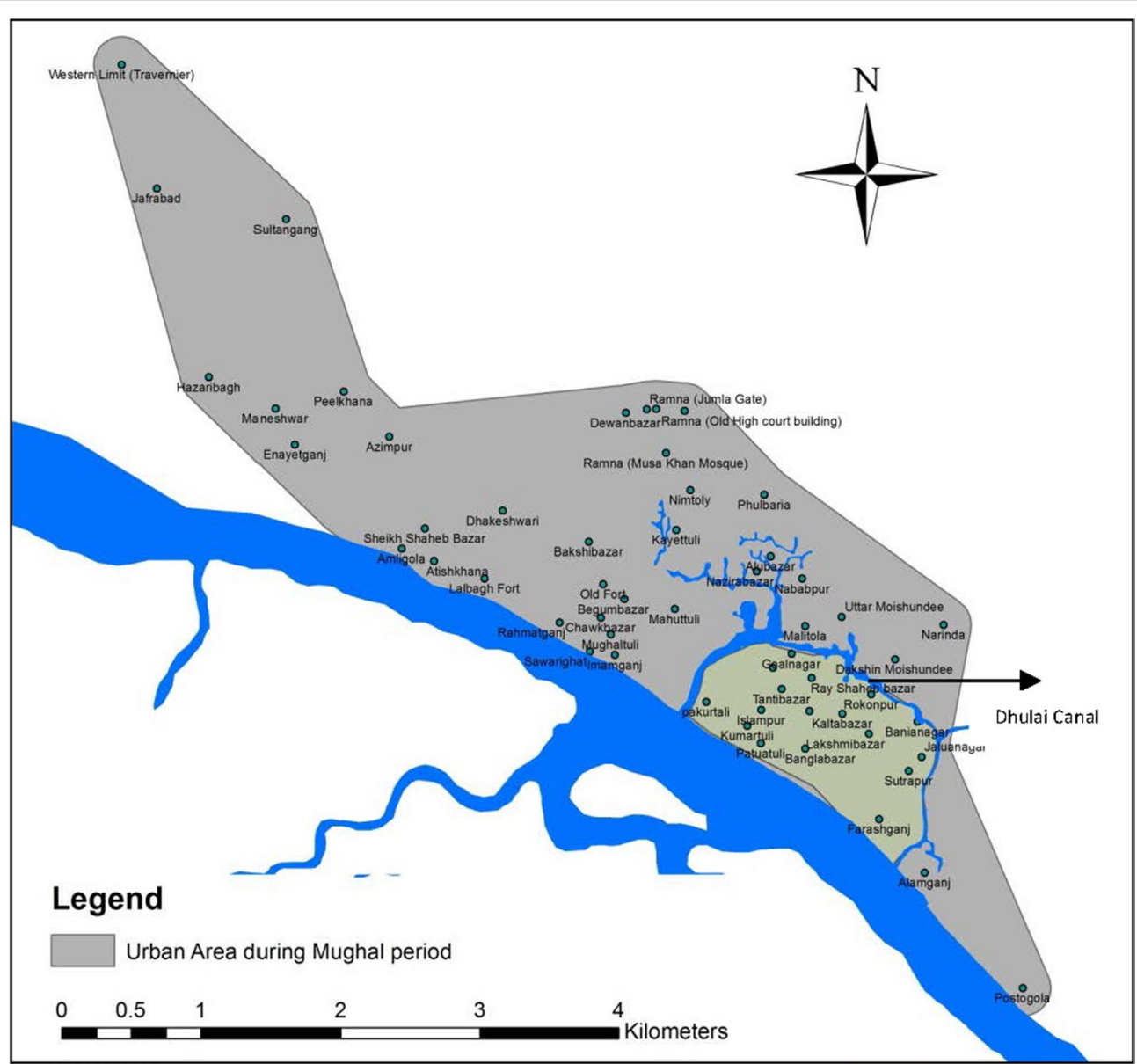

Fig. 4 Urban boundary of Dhaka in Mugh period (polygon created with ShrinkHull algorithm) 
Table 3 Spatial extent of the top Mughal cities in 17th century

\begin{tabular}{|c|c|c|c|}
\hline Cities & Travelers & Description about the extent of the cities & Source \\
\hline Agra & Francisco Pelsaert (1627) & $\begin{array}{l}\text { The length of Agra was } 6 \text { kos ( } 12 \text { miles) } \\
\text { including its suburbia and the breadth of } \\
\text { the city was "by no means as great as the } \\
\text { length" }\end{array}$ & Pelseart (1925) \\
\hline $\begin{array}{l}\text { Shahjahanabad } \\
\text { (Delhi) }\end{array}$ & John Campbell (1668) & $\begin{array}{l}\text { Shahjahanabad extended three to four miles } \\
\text { from north to south as described by John } \\
\text { Campbell in } 1668 \text {. The city was limited to } \\
1500 \text { acres ( } 6.07 \mathrm{sq} \mathrm{km} \text { ) within the walled } \\
\text { enclosure. However, by } 18^{\text {th }} \text { century the city } \\
\text { expanded beyond the wall and the area } \\
\text { including its suburbia reached } 3300 \text { acres. }\end{array}$ & $\begin{array}{l}\text { Blake (2002) } \\
\text { y }\end{array}$ \\
\hline Lahore & William Finch (1611) & $\begin{array}{l}\text { William Finch travelled Lahore in } 1611 \text { and } \\
\text { described it as 'one of the greatest cities in } \\
\text { the east'. According to Finch, the city was } \\
10 \text { miles in length. }\end{array}$ & $\begin{array}{l}\text { Finch Finch (1921), Thompson Thomson } \\
\text { (1851) }\end{array}$ \\
\hline Ahmadabad & Johan Mandelslo (1638) & $\begin{array}{l}\text { The city was seven leagues ( } 21 \text { miles) in } \\
\text { compass including the suburban areas and } \\
\text { adjacent villages }\end{array}$ & Gazetteer (1879) \\
\hline Surat & John Ovington & $\begin{array}{l}\text { The circumference of the city, with the } \\
\text { suburb, is between two and three miles, } \\
\text { tending somewhat in its position to the } \\
\text { form of a semicircle }\end{array}$ & Ovington (1929) \\
\hline Fatehpur Sikri & William Finch (1610) & \multicolumn{2}{|c|}{$\begin{array}{l}\text { The length of the city was } 2 \text { or } 3 \text { cos in length Finch (1921) } \\
\text { (4-6 miles) }\end{array}$} \\
\hline Patna & Peter Mundy (1632) and Tavernier (1665) & $\begin{array}{l}\text { Peter Mundy in } 1632 \text { noted that the city } \\
\text { was } 3 \text { miles long; while Tavernier in } 1665 \\
\text { estimated that it was not less than } 4 \text { miles } \\
\text { in length. }\end{array}$ & $\begin{array}{l}\text { Tavernier (1889) } \\
\text { Jha (2005) }\end{array}$ \\
\hline Calicut & John Fryer (1672-1681) & $\begin{array}{l}\text { The city as Fryer described was maximum } 4 \\
\text { miles in length }\end{array}$ & Fryer (1698) \\
\hline
\end{tabular}

$9.6 \mathrm{~km}$ while its breadth is measured $2.5 \mathrm{~km}$ in northsouth direction (From Sawarighat to Ramna). In that time it was one of the largest cities not only in Bengal but also in the entire Mughal Empire. The area of the city was comparable with any other top cities of the world in the 17th century. In that time, the major cities of Mughal Empire were Agra, Fatehpur Sikri, Delhi, Lahore, Ahmedabad, Patna, Burhanpur, Cochin and Surat (Chaudhury 1978; Roy 2013). For a comparative analysis of the city size of Dhaka with other Mughal cities, the textual description of different travelers featuring the extent of the cities of that time was considered (Table 3). From their description it can be easily perceived that, only Agra, Lahore and Ahmedabad had greater size than Dhaka. Again, Agra, Delhi, Lahore were the cities comparable to any other top cities in the west. Bernier mentioned that area of Delhi was not much smaller than Paris, and Agra was larger than Delhi (Bernier 1891). Fitch said that both Agra and Fatehpur Sikri were individually much larger than London (Eraly 2007). Considering these statements, it will not be an exaggeration to place Dhaka as one of the top cities of the world in 17 th century.

\section{Spatial analysis with georeferenced data} Quantifying the area of urban territory and the spatial pattern of the localities

The maps generated in GIS create a scope for a spatial analysis of urban expansion of Dhaka in pre and post Mughal periods. In pre-Mughal period the area has been calculated as $1.55 \mathrm{sq} \mathrm{km} \mathrm{embedded} \mathrm{by} \mathrm{the} \mathrm{Dhuali} \mathrm{River.}$ During the Mughal period many new areas, mentioned above came under human settlement during this time and the city expanded to $12.93 \mathrm{sq} \mathrm{km}$ in area. However, the growth of Dhaka lost its momentum after the capital was transferred to Murshidabad in 1717 (Dani 1962). But Dhaka as a city was important not only for administrative reasons but also for the business activities and revenue collection. That is why in spite of losing the status of capital Dhaka did not decline. But the building activities certainly stopped and the city did not actually expand during the last 50 years of Mughal era.

In post Mughal era when colonial power took the control the city started to lose its glory. In fact, the area of the city had shrunk during this time. Many areas where administrative officials and the related personals resided were abandoned. The Surveyor General's Map of 1859 


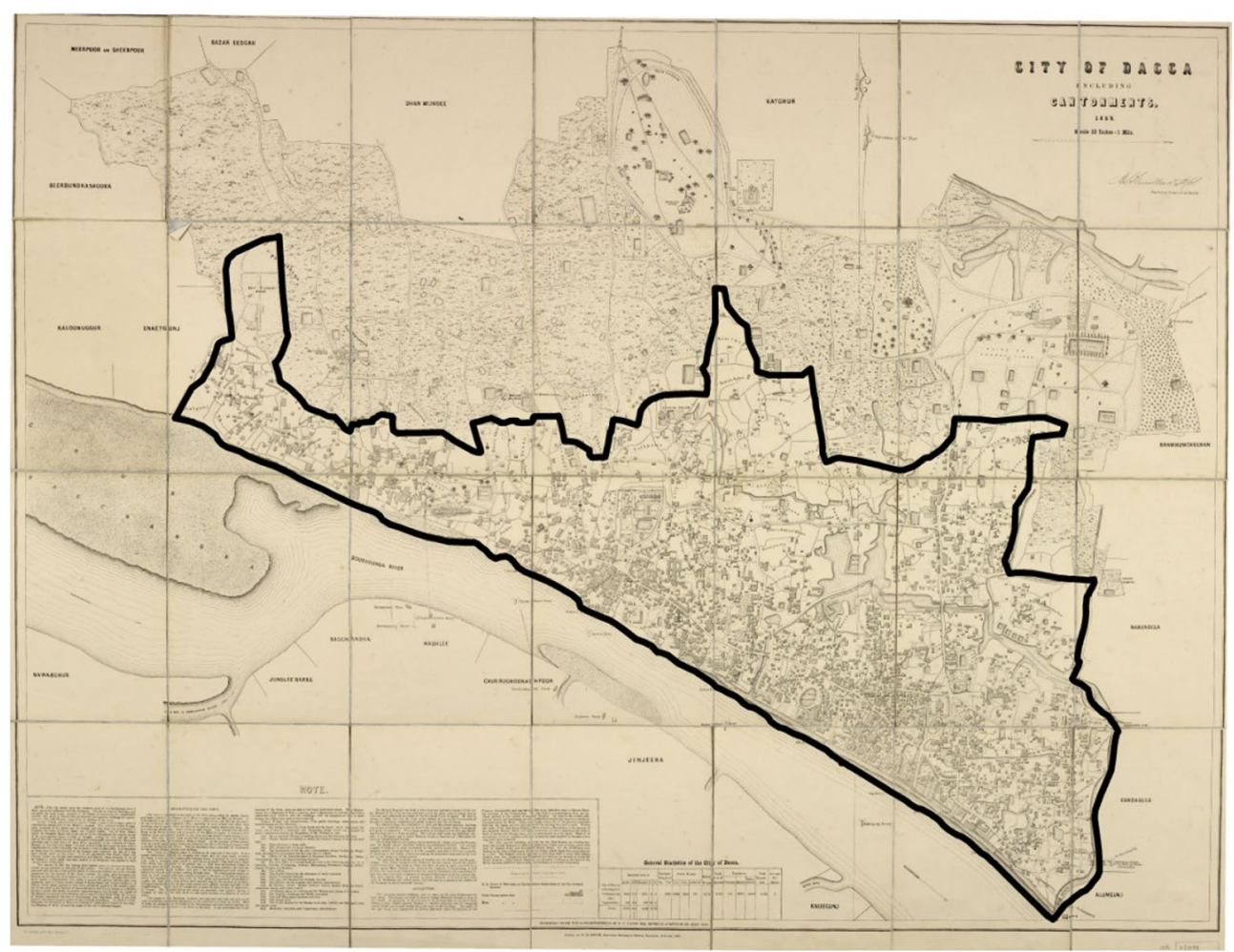

Fig. 5 Urban area of Dhaka in post-Mughal period (Surveyor General's Map 1859)

shows that the urban area declined to $5.4 \mathrm{sq} \mathrm{km}$ from $12.93 \mathrm{sq} \mathrm{km}$ in that time (Figs. 5, 6). That means $58.24 \%$ of the Mughal areas declined due to de-urbanization in colonial period. The decline was most prominent in west and north of the core city. Once the vibrant urban localities located in the west: Jafrabad, Hazaribagh, Maneshwar, Enayetganj, Sultanganj, Azimpur became depopulated. Also, the area Ramna and its west (Mahalla Shujatpur and Mahalla Chishtia), Phulbaria, Narinda, Alamganj, Postgola declined in that time. The ruined areas were turned into an overgrown jungle.

The spatial pattern of the localities in Mughal times can be better understood by average nearest neighbor (ANN) analysis. It illustrates that the distribution of the localities show a dispersed pattern (NN ratio greater than 1) (Table 4). However, a distinction can be drawn in between old pre-Mughal and the newly developed Mughal areas. The average nearest neighbor distance of pre-Mughal localities is $193.34 \mathrm{~m}$ and that of newly developed Mughal localities is $380.17 \mathrm{~m}$. It implies a higher concentration of localities in Pre-Mughal area. This was more densely populated area inhabited by artisan classes of people. On the contrary, the Mughal localities were comparatively more spaced. These were the areas resided by high class Mughals. Although Mughals did not build extensive garden villas in Dhaka like other imperial Mughal cities in Northern India, the city could not avoid the inheriting Mughal style and influence. The newly built city was adorned with palaces with open spaces and gardens. Bag-e-Badshahi, the garden in front of the old fort and the Lalbagh fort are the examples of great Mughal gardens in Dhaka within the main city. There were open squares with public buildings-Katras and mosques. Thus the newly developed Mughal localities in the west and the north made a clear distinction with the compactly built old pre-Mughal localities.

\section{Geological aspect of urban development}

Geology always has always a significant role in the formation and growth of settlements. Dhaka is no exception. Historically Dhaka's development responded well with the hydrographical and geological realities of the place. It was well placed on relatively higher ground surrounded by the floodplains. The spatial development followed the prong of flood free elevated terrace. The geo-morphological map, prepared by Geological Survey of Bangladesh (Fig. 7) illustrates the geological formations based on surface morphology and land elevation (GSB 2014). The map of Mughal Dhaka was overlaid on the geo-morphological map to understand how hydro-geological settings of 


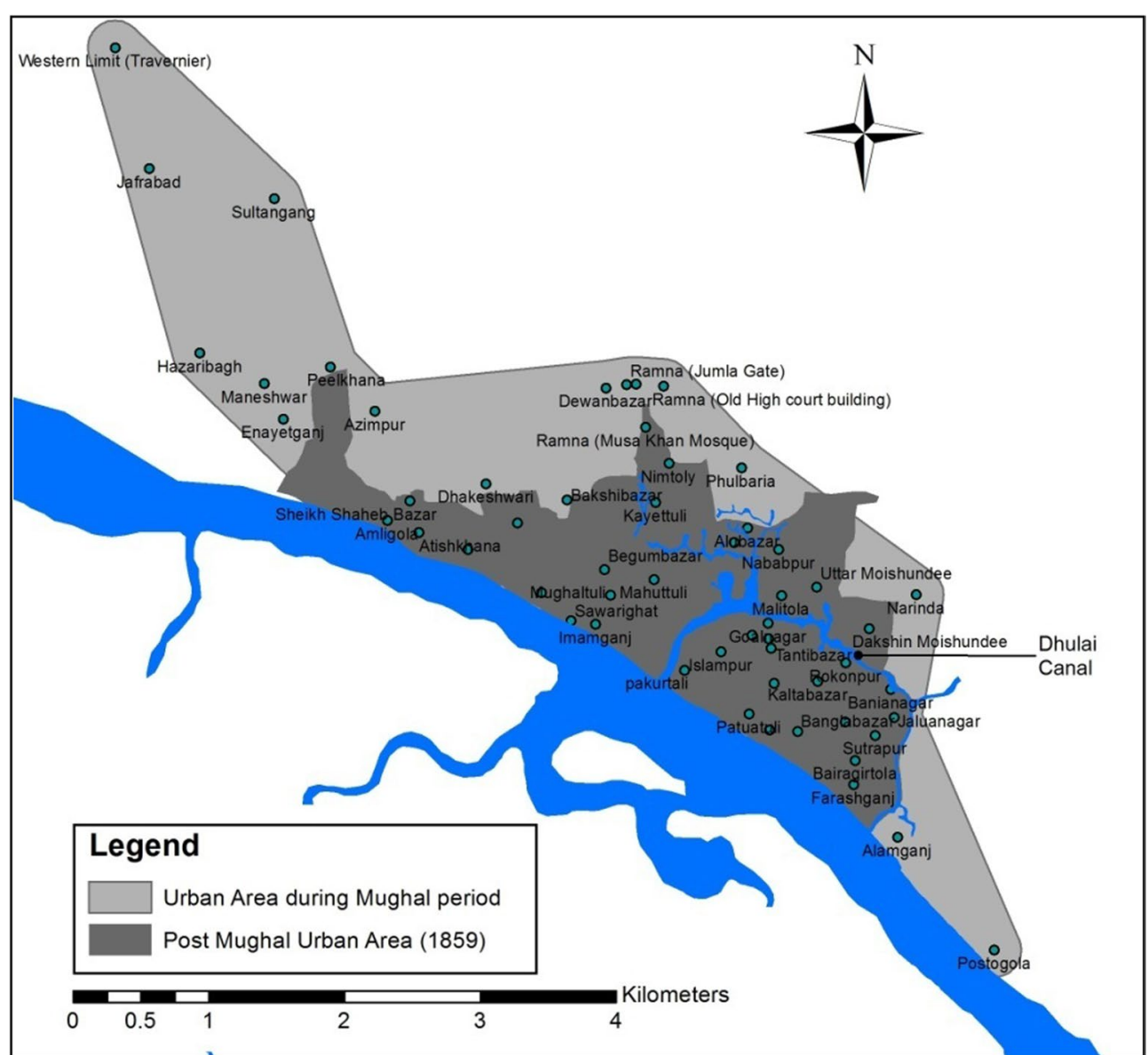

Fig. 6 Temporal change of urban territory of Dhaka in Mughal and post-Mughal period

Dhaka had major influence on its spatial development in early times. The first urbanization of Dhaka took place in the old natural levee unit in pre-Mughal period. From the geomorphic map it is evident that the strip of old natural levee was directed towards the west from the early settlements. Also, a good amount of high land was available in the west and north. That is why the spatial development of Dhaka in Mughal times took place mostly in the west and then in the north. The extension in the east was restricted by the availability of suitable land. However, certain areas in the west of the pre-Mughal area-Alamganj, Farashganj and Postgola came under the development to the extent where the old natural levee along the riverside was available. GIS analysis shows that $54.82 \%$ of the newly developed areas were on the old natural levee while $31.80 \%$ were on the high Modhupur terrace (Table 5). For being flooded annually, it was not possible to bring the low lying floodplains under the development. Moreover, there was little scope to adorn the city with spacious gardens like other Mughal cities in India
Table 4 Average nearest neighbor (ANN) analysis

\begin{tabular}{llllc}
\hline $\begin{array}{c}\text { Spatial extent } \\
\text { NN (nearest } \\
\text { neighbor) ratio }\end{array}$ & $\begin{array}{l}\text { Average } \\
\text { nearest } \\
\text { neighbor } \\
\text { distance } \\
\text { (ANN) (m) }\end{array}$ & P value & $\begin{array}{l}\text { Area (in sq } \\
\mathbf{k m})\end{array}$ \\
\hline $\begin{array}{l}\text { Pre-Mughal area1.34 } \\
\begin{array}{l}\text { Mughal exten- } \\
\text { sion }\end{array}\end{array}$ & 1.32 & 380.17 & $P<0.01$ & 11.38 \\
\begin{tabular}{l} 
Total \\
\hline
\end{tabular} & 1.23 & 302.88 & $P<0.01$ & 12.93 \\
\hline
\end{tabular}

limited by the availability of the suitable land. This created a special distinction of Dhaka with other major cities of Mughal regime. The city followed the characteristics riparian pattern along the natural levee, as compared with the stable waterfront development in Agra, the upland river terrace and plains development in Delhi and Lahore. 


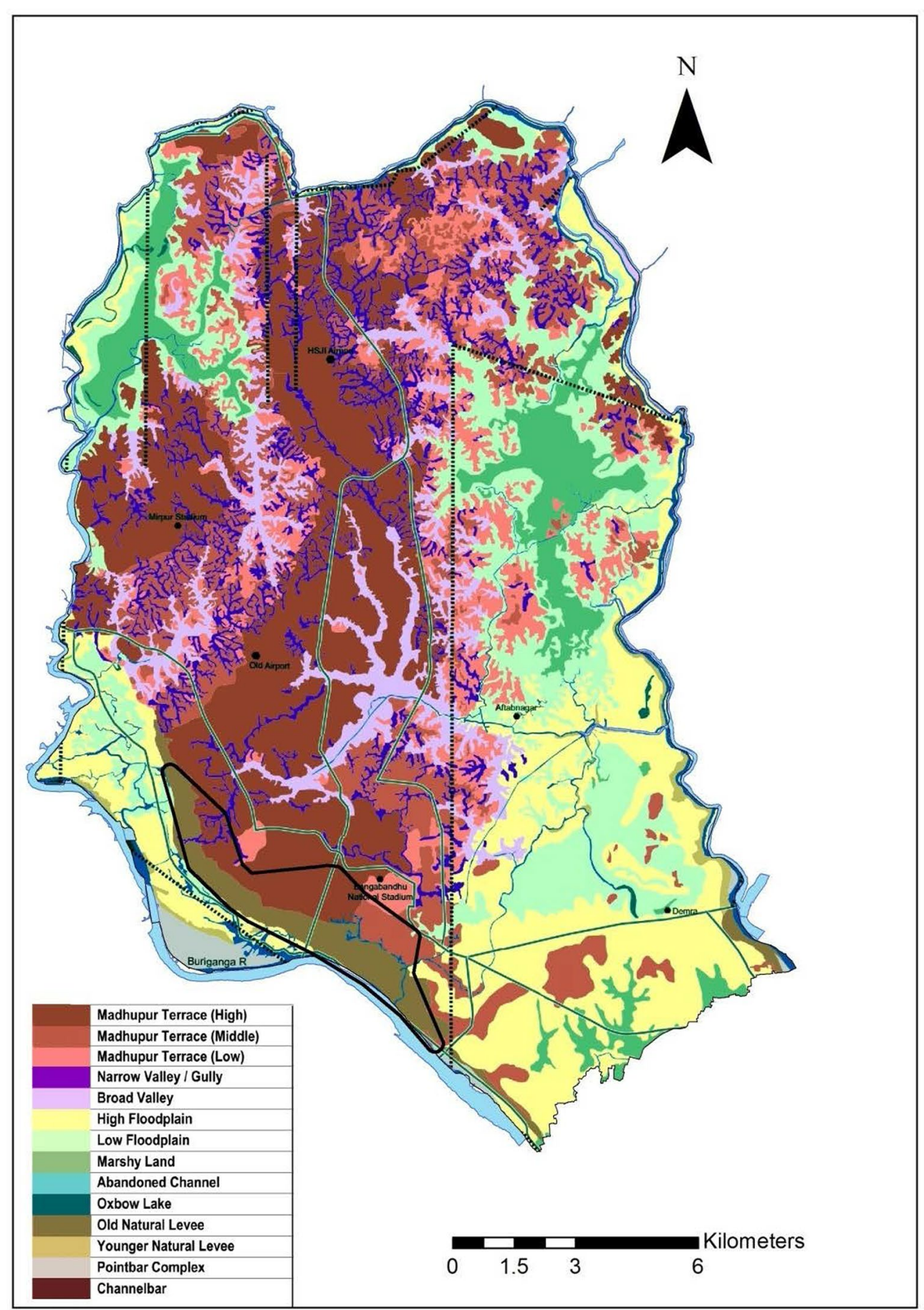

Fig. 7 An overlay of Dhaka's Mughal area over the geo-morphological map Source: Geological Survey of Bangladesh (GSB 2014)

\section{Conclusion}

The method of historical GIS as a combination of both qualitative and quantitative approach can open a new dimension of historical study. For spatial representation of past urban territory this study has applied GIS as advanced cartographic and spatial analysis techniques which have not used by any researcher till to date to study the past history of Dhaka. Examining a good number of materials corresponding to this field, a new methodology has been proposed here which goes beyond only 
Table 5 Urban development on different geo-morphological units during Mughal period

\begin{tabular}{lll}
\hline $\begin{array}{l}\text { Geo-morphological } \\
\text { units }\end{array}$ & $\begin{array}{l}\text { Elevation (above mean } \\
\text { sea level) }\end{array}$ & \% of urban area \\
\hline Old natural levee & $>6 \mathrm{~m}$ & 54.82 \\
$\begin{array}{l}\text { Modhupur terrace (high) } \\
\text { Modhupur terrace }\end{array}$ & $>6 \mathrm{~m}$ & 31.80 \\
$\quad$ (medium) & $4-6 \mathrm{~m}$ & 10.43 \\
High flood plain & $2-4 \mathrm{~m}$ & 1.97 \\
Others & - & 0.98 \\
\hline
\end{tabular}

studying the past locations and generation of maps. In a comparative or evolutionary perspective, the map of past urban territory enables sequential and overlapping visualizations and can be combined with data from different origins and natures if spatially referenced in the same support. It will stimulate further thinking about the methodological and conceptual possibilities of historical GIS. Its methodological prospects and application will not only be limited in context of Dhaka, but for other cities as well.

The spatiotemporal analysis of human settlement in this study reveals the past landscape of Dhaka and the way they have changed throughout the times. Reviewing the important documents and historical studies, it has tried to define the past extent of Mughal Dhaka which has been missing till now. These mappings provide a strong visual portrayal of recognized growth patterns, and dramatically convey how the progress of modern urbanization results in profound changes to the landscape.

\section{Authors' contributions}

MR conceived of the study, carried out required literature review, performed analysis in GIS, drafted the manuscript and coordinated the whole work; KZ participated in digitizing maps and performed analysis in GIS; RH conceived of the study, and supervised the whole work. All authors read and approved the final manuscript.

\section{Competing interests}

The authors declare that they have no competing interests.

Received: 7 April 2016 Accepted: 30 May 2016

Published online: 13 June 2016

\section{References}

Ahmed SU (1986) Dacca: a study in urban history and development. Curzon Press, London

Alexander N (2015) On literary geography. literary geographies I (1). http:// www.literarygeographies.net/index.php/LitGeogs/article/view/1-2/ pdf_8. Accessed 1 Sep 2015

Alves D, Queiroz I (2013) Studying urban space and literary representations using GIS. Soc Sci Hist 37(4):457-481. http://run.unl.pt/bitstream/10362/11033/1/Alves_Queiroz_2013_Studying\%20urban\%20 space\%20and\%20literary\%20representations\%20using\%20GIS(preprint). pdf. Accessed 6 May 2015
Auer MT (2009) "Mapping data—specific avian distributions utilizing cartographic point aggregating generalization operators in a multi-scale framework". Proceeding of the fourth international partners in flight conference: Tundra to Topics, US. http://www.divaportal.org/smash/get/ diva2:495816/FULLTEXT01.pdf. Accessed 10 Jan 2015

Ayers EL (2010) Turning toward place, space, and time. In: Bodenhamer DJ, Corrigan J, Harris TM (eds) The spatial humanities: GIS and the future of humanities scholarship. Indiana University Press, Bloomington

Baker AR (2003) Geography and history: bridging the divide. Cambridge University Press, Cambridge

Berman ML (2005) Boundaries or networks in historical GIS: concepts of measuring space and administrative geography in Chinese history. Hist Geogr 33:118-133

Bernier F (1891) Travels in the Mogul Empire, AD 1656-1668. Archibald Constable (Trans). Oxford University Press, London. https://www.archive.org/ details/travelsinmogulem00bernuoft. Retrieved 4 Apr 2016

Blake SP (2002) Shahjahanabad: the Sovereign city in Mughal India 1639-1739, vol 49. Cambridge University Press, Cambridge

Butlin RA (1993) Historical geography: through the gates of space and time. E. Arnold, London

Chaudhury KN (1978) Some reflections on the town and Country in Mughal India. Mod Asian Stud 12(1):77-96

Cooper D, Gregory IN (2011) Mapping the english lake district: a literary GIS. Trans Inst Br Geogr 36:89-108. doi:10.1111/j.1475-5661.2010.00405.x

Dani AH (1962) Dacca: a record of its changing fortunes. Asiatic Press, Dacca

Darby HC (1962) Historical geography. In: Finberg HPR (ed) Approaches to history. Routledge, London, pp 127-156

Dewan A, Corner R (2013) Dhaka megacity: geospatial perspectives on urbanisation, environment and health. Springer Science \& Business Media, Berlin

Doherty P, Guo Q, Liu Y, Wieczorek J, Doke J (2011) Georeferencing incidents from locality descriptions and its applications: a case study from Yosemite National Park search and rescue. Trans GIS 15(6):775-793

Eraly A (2007) The Mughal World: life in India's last golden age. Penguin Books India, Delhi

Ferdous F (2012) The spatial analysis and morphological evolution of the 'Bazaar Streets' and urban structure of Dhaka city. Urban Des Int 17(3):206-220

Fryer J (1698) A new account of East-India and Persia, in eight letters. Ri. Chiswell, London. https://archive.org/details/anewaccounteast00whitgoog. Retrieved 4 Apr 2016.

Gazetteer (1879) Gazetteer of the Bombay Presidency: Ahmedabad. Government Central Press, Ahmedabad

Gregory IN, Healey RG (2007) Historical GIS: structuring, mapping and analysing geographies of the past. Prog Hum Geogr 31(5):638-653

Gregory IN, Bennett C, Gilham VL, Southall HR (2002) The Great Britain historical GIS Project: from maps to changing human geography. Cartogr J 39:37-49

GSB (Geological Survey of Bangladesh) (2014) Geomorphologic map of greater Dhaka City, Bangladesh. Geological Survey of Bangladesh, Dhaka. http://www.bgr.bund.de/EN/Themen/Zusammenarbeit/ TechnZusammenarb/Downloads/bangladesh_geomorphology.pdf? blob=publicationFile\&v=2. Retrieved 4 Apr 2016

Haider A (1967) Dacca: history and romance in place names. Asiatic Society of Bangladesh, Dhaka

Holdich TH (1916) Political frontiers and boundary making. Macmillan and Company, New York

Hossain MS (2013) Strategies to integrate the Mughal settlements in Old Dhaka. Front Arch Res 2(4):420-434

Hu P, Qingwen Q, Zhaoli L (2004) Progress in studies on automated generalization of spatial point cluster. In: Geoscience and remote sensing symposium. IGARSS'04. Proceedings. 2004 IEEE international, vol 5. IEEE, pp 2841-2844

Islam N (1996) Dhaka: From city to Megacity: perspectives on people, places, planning and development issues. Urban Studies Programme, Department of Geography, University of Dhaka, Dhaka

Jalali L, Keivani FS (2013) An investigation of historical geography. J Humanit Soc Sci 17(2):26-30

Jha SK (2005) A new dawn: Patna reincarnated. Sudhir Kumar Jha, Patna

Jones SB (1932) The forty-ninth parallel in the great plains: the historical geography of a boundary. J Geogr 31(9):357-368 
Kabir A, Parolin B (2012) Planning and development of Dhaka-a story of 400 years. In: 15th international planning history society conference, cities, nations and regions in planning history, Sao Paulo, p 1-20)

Kamal ASMM, Midorikawa S (2004) GIS-based geomorphological mapping using remote sensing data and supplementary geoinformation: a case study of the Dhaka city area, Bangladesh. Int J Appl Earth Obs Geoinf 6(2):111-125

Karim A (1964) Dacca: the Mughal capital. Asiatic Society of Pakistan, Dhaka Knowles AK (ed) (2008) Placing history: how maps, spatial data, and GIS are changing historical scholarship. ESRI Press, Redlands

Mamoon M (1993) Dhaka: Smriti Bismritir Nogori. Ononna Publication, Dhaka

Mishu MR, Barua U, Stoican IA (2014) The changing nature of urban public places in Dhaka City. Urban Arhit Constr 5(4):5-16

Mitchell JB (1954) Historical geography. English universities Press, London

Mowla QA (1997) Settlement texture: study of a Mahalla in Dhaka. J Urban Des 2(3):259-275

Nathan M (1936) Baharistan-i-Ghayibi. (Borah, M.I., Trans). Government of Assam in the Department of Historical and Antiquarian Studies, Narayani Handiqui Historical Institute, Gauhati. https://www.ia600307. us.archive.org/15/items/baharistanghaybi031110mbp/baharistanghaybi031110mbp.pdf. Accessed 15 Dec 2014

Nilufar F (1997) The spatial and social structuring of local areas in Dhaka city-a morphological study of the urban grid with reference to neighborhood character within naturally — grown areas. Unpublished Doctoral Thesis. Unit for advanced architectural studies, the Bartlett School of Graduate Studies, University College London, University of London, London

Nilufer $\mathrm{F}$ (2004) Hidden morphological order in an organic city. Protibesh 9:34-41

Ovington J (1929) A Voyage to Surat in the year 1689. In: Rawlinson HG (ed) London

Pelseart F (1925) Jahangir's India: the remonstratie of F. Pelseart. In: Moreland WH, Geyl P (eds) Cambridge. https://www.archive.org/details/jahangirsindia035084mbp. Retrieved 4 Apr 2016

Philo C (2000) More words, more worlds: reflections on the "cultural turn" and human geography. In: Cook I, Crouch D, Naylor S, Ryan JR (eds) Cultural turns/geographical turns: perspectives on cultural geography. Prentice, Harlow

Piatti B, Hurni L (2007) Towards a European atlas of literature: developing theories, methods, and tools in the field of 'literary geography'. In: XXII international cartographic conference ICC, Moscow. http://www.icaci. org/files/documents/ICC_proceedings/ICC2009/html/nonref/24_1. pdfAccessed 16 July 2015

Piatti B, Reuschel AK, Bar HR, Cartwright W, Hurni L (2009) Mapping literature towards a geography of fiction. In: Cartwright W, Gartner G, Lehn A (eds) Cartography and art. Springer, Wiesbaden

Rabbani G (1997) Dhaka: from Mughal outpost to metropolis. University Press Limited, Dhaka
Rahman HH (1991) Asugdan-E-Dhaka. (Farukh A, Chouedhury RA, Trans.) Asiatic Society of Bangladesh, Dhaka

Rahman MR, Zaman K, Islam A (2014) Analyzing the spatial development of human settlement in Dhaka, unpublished BURP thesis, department of Urban and Regional Planning. Bangladesh University of Engineering and Technology, Dhaka

Rainsford D, Mackaness W (2002) Template matching in support of generalization of rural buildings. In: Richardson D, van Oosterom P (eds) Advances in spatial data handling. Proceedings 10th international symposium on spatial data handling. Springer, Berlin, p 137-151

Ray BC (2002) Teaching the Salem witchcraft trials. In: Knowles AK (ed) Past time, past place: GIS for history. ESRI Press, Redlands, pp 19-33

Revell P (2004) "Building on past achievements: generalizing OS master map rural buildings to 1:50,000". ICA workshop on generalization and multiple representation, 20-21 August 2004, Leicester

Roy T (2013) An economic history of early modern India. New York: Routledge

Shamsuzzoha ATM, Islam H (2011) Structure, decoration and materials: Mughal Mosques of medieval Dhaka. J Bangladesh Assoc Young Res 1(1):93-107

Sharp W (1904) Literary geography. Pall Mall Publications, London

Skinner GW, Henderson M, Jianhua Y (2000) China's fertility transition through regional space. Soc Sci Hist 24:613-652

Smith GA (1894). The historical geography of the holy land: especially in relation to the history of Israel and of the early church. Hodder \& Stoughton, London

Smith GA, Bartholomew JG (eds) (1915) Atlas of the historical geography of the Holy Land. Hodder \& Stoughton, London

Soja E (1989) Postmodern geographies: the reassertion of space in critical social theory. Verso, London and New York

Taifoor SM (1956) Glimpses of old Dhaka. c, Dacca

Tavernier JB (1889) Travels in India. In: Ball V, Trans. Oxford University Press, London (Original work published in 1676). https://www.archive.org/details/ travelsinindia00tavegoog. Retrieved 4 Apr 2016

Taylor J (1840) A sketch of the topography and statistics of Dacca. Military Orphan Press, Calcutta. https://archive.org/stream/asketchtopograp00taylgoog/asketchtopograp00taylgoog_djvu.txt. Accessed 15 Dec 2013

Thomson J (1851) The new universal gazetteer and geographical dictionary. In Bohn HG (ed), London

Wieczorek J, Guo Q, Hijmans R (2004) The point-radius method for georeferencing locality descriptions and calculating associated uncertainty. Int J Geogr Inf Sci 18(8):745-767

Wieczorek J, Bloom D, Constable H, Fang J, Koo M, Spencer C, Yamamoto K (2012) Georeferencing quick referencing guide. https://www.idigbio.org/ wiki/images/1/1e/GeoreferencingQuickReferenceGuide.pdf

William Finch (1921) Early travels in India; 1583-1619. In: Foster W (ed) Oxford University Press, Oxford

Woolf V (1977) 'Literary geography.'Books and portraits. In: Lyon M (ed) Hogarth Press, London

\section{Submit your manuscript to a SpringerOpen ${ }^{\odot}$ journal and benefit from:}

- Convenient online submission

- Rigorous peer review

- Immediate publication on acceptance

- Open access: articles freely available online

- High visibility within the field

- Retaining the copyright to your article

Submit your next manuscript at springeropen.com 